\title{
Effect of Weed Management Interventions on Soil Microbial Count in Wheat and Direct Seeded Basmati Rice in Irrigated plains of Shivalik Foothills of Jammu
}

\author{
Akhil Verma*, B. C. Sharma, Brij Nandan, Rakesh Kumar and Monika Banotra \\ Sher-e Kashmir University of Agricultural Sciences and Technology, Chatha, \\ Jammu and Kashmir 180009, India \\ *Corresponding author
}

A B S T R A C T

\begin{tabular}{|l|}
\hline K e y w o r d s \\
$\begin{array}{l}\text { Wheat, Direct } \\
\text { seeded basmati rice, } \\
\text { microbes, Weed } \\
\text { management }\end{array}$ \\
\hline Article Info \\
\hline $\begin{array}{l}\text { Accepted: } \\
\text { 10 July 2020 } \\
\text { Available Online: } \\
\text { 10 August } 2020\end{array}$ \\
\hline
\end{tabular}

A field experiment was conducted for two consecutive years from rabi seasons of 2013-14 and 2014-15 to kharif seasons of 2014 and 2015 at Research Farm Chatha, Division of Agronomy, Sher-e-Kashmir University of Agricultural Sciences and Technology, Jammu to assess the dynamics of the soil microbes in wheat (Triticum aestivum L.) - direct seeded basmati rice (Oryza sativa L.) crop sequence under the influence of different weed management interventions. The results of the study reveals that soil microbial count with regard to bacteria, fungi and actinomycetes on the experimental site at 15 and 30 days after the imposition of the treatment registered significant reduction in the soil microbial population in herbicide treated plots over weedy check and mechanical weedings (at 30 and 60 DAS). However, slight increase in the counts of soil micro-organisms were observed at 30 days after the application of herbicides in comparison to their initial counts that were recorded 15 days after the imposition of herbicide treatments. The results imply a recovery in the soil microbial population after initial reduction following the use of herbicides at recommended rates. Consequently no deleterious effects on soil biological health and crop yields were noticed. Instead, the application of herbicides reduced the weed menace to a greater extent resulting in higher crop yields.

\section{Introduction}

Wheat (Triticum aestivum L.) is a staple food of nearly 2.5 billion human population across the globe (Ramdas et al., 2019) and about one third of the world's population rely on wheat crop for its protein and energy requirements (Khan, 2003). World production of wheat during 2017-18 touched to 763.1 million tonnes from an acreage of 220 million hectare with productivity of $3.47 \mathrm{t} / \mathrm{ha}$ (USDA, 2019). India stands first in area under wheat $(30.60$ million hectare) covering $14 \%$ of the global wheat area while in production India ranks second with 99.7 million tonnes which constitutes nearly $13.4 \%$ of the world's wheat production having productivity of $3.40 \mathrm{t} / \mathrm{ha}$ (Ramdas et al., 2019). In the UT of Jammu and Kashmir also wheat is considered as the second most significant crop followed by 
maize with an area, production and productivity of 0.29 million hectares, 0.47 million tonnes and $1.62 \mathrm{t} / \mathrm{ha}$, respectively (Anonymous, 2017). Despite wheat a premium crop at international, national and UT level, weeds are the major limitation in optimizing the productivity of wheat. Heavy weed infestations can cause complete crop losses and decrease in the yield of crops (Hussain et al., 2008). Due to the presence of weeds yield reductions in wheat can range from 15 to $50 \%$ based on the type and the infestation of weed flora. According to Angiras et al., (2008) Kumar et al., (2009) and Kumar et al., (2011), the losses can be even more based on the weed densities, type of weed flora and duration of infestation. On the other hand, rice (Oryza sativa L.) is a also very significant crop of the world cultivated in about 114 countries, out of which more than 50 countries have an annual production of about 0.1 million tonnes or just more (FAO, 2010).

The global production of rice during 2017-18 recorded to be 495.4 million tonnes from an area of 162.61 million hectares with an average yield of $4.55 \mathrm{t} / \mathrm{ha}$ (USDA, 2019). In India too rice is the major crop having vital role in the country's food security. In the year 2017, rice grain production was 110.15 million tonnes which was realized from 43.19 million hectares of land recording an average grain yield of $2.25 \mathrm{t} / \mathrm{ha}$ (Anonymous, 2017). Likewise, in Jammu and Kashmir rice production of 0.57 million tonnes rice grain was obtained from an area of 0.28 million hectares with a productivity of $2.02 \mathrm{t} / \mathrm{ha}$ (Anonymous, 2016-17). Among different rice varieties cultivated in the country, aromatic rice cultivars are the most unique which are relished by the consumers and fetch higher returns as compared to the other rice types. In Jammu region of the Jammu and Kashmir, the total area under rice is 102.22 thousand hectares (Anonymous, 2016-17), out of which about 62.4 thousand hectares is under different types of basmati cultivars and amongst them Basmati-370 is predominant in the region with an acreage of 53.9 thousand ha recording production of 91 thousand tonnes (Anonymous, 2018). Rice is grown by two cultural methods - transplanting and direct seeding. Direct seeding is a practical option in the face of shortage and high cost of labor. Rice - wheat system is the most widespread cropping systems throughout the world, In India also, rice-wheat cropping system provides food security to $77 \%$ of the country's population. However, the weeds are the major impediment in achieving productivity of this system. The condition turn out to be gloomy with the introduction of direct seeded culture in rice-wheat cropping system as weeds are the major limiting factor in the successful production of direct seeded rice. Weed flora in direct-seeded rice badly affect the yield, quality and increase cost of production as a result of competition of various growth factors and the yield loss varied from $10 \%$ to complete failure of the crop depending upon the situation Johnson (1996).

Weed control in wheat and rice through herbicides is becoming increasingly popular due to their efficient and cost effective control of weeds. But the control of weeds through chemical herbicides always raise concerns about their possible negative impacts on soil health as they may upset the equilibrium of soil microflora thereby influencing the future soil fertility and the general growth and development of crop plants (Schuster and Schroder,1990) ultimately affecting the crop yields. Keeping the above facts in view the studies on the soil microbial population in Wheat-direct seeded basmati rice cropping sequence under the influence of different weed management interventions in the irrigated plains of Shivalik foothills of Jammu were carried out. 


\section{Materials and Methods}

A field experiment was conducted consecutively for two years starting from $r a b i$ season of 2013-14 up to the kharif season of 2015 at Research Farm Chatha, Division of Agronomy, Sher-e-Kashmir University of Agricultural Sciences and Technology, Jammu. The experimental site was located at $32^{\circ}-40 \mathrm{~N}$ latitude and $74-58^{\circ} \mathrm{E}$ longitude at an altitude of 332 meter above mean sea level in the Shivalik foot hill plains of North-Western Himalayan region. The soil of the experimental field was sandy clay loam in texture, slightly alkaline in reaction, low in available nitrogen $(242.60 \mathrm{~kg} / \mathrm{ha})$, medium in organic carbon $(0.45 \%)$, phosphorous $(12.98$ $\%)$ and potassium $(154.40 \mathrm{~kg} / \mathrm{ha})$. Initially the experiment started in the of rabi 2013-14, laid out in randomised block design for wheat crop while during kharif season of 2014 the layout was converted into split-plot design for direct seeded basmati rice considering weed management approaches of wheat crop as main plot treatments and weed management approaches of direct seeded basmati rice as sub-plot treatments. The five weed management treatments viz., Weedy check; Mechanical weedings twice at 30 and 60 DAS; Isoproturon@1.0 kg/ha + 2,4- D @ 0.500 1/ha (PoE); Clodinafop @ $0.060 \mathrm{~kg} / \mathrm{ha}$ (PoE) and Triasulfuron @ $0.015 \mathrm{~kg} / \mathrm{ha}(\mathrm{PoE})$ applied in wheat whereas in basmati rice each treatment plot of wheat was split into four sub-plots and the weed management treatments of direct seeded basmati rice consisted of Weedy check; Mechanical weedings-twice at 30 and 60 DAS; Pendimethalin @ $1.0 \mathrm{~kg} / \mathrm{ha} \quad(\mathrm{PE})$; Pendimethalin @ $1.0 \mathrm{~kg} / \mathrm{ha} \quad(\mathrm{PE}) \quad f b$ Bispyribac@0.030 kg/ha (PoE). The crops were sown manually in lines $20 \mathrm{~cm}$ apart with seed rate of 100 and $40 \mathrm{~kg} / \mathrm{ha}$ for wheat and rice, respectively. A uniform recommended dose of $\mathrm{N}(100 \mathrm{~kg} / \mathrm{ha}), \mathrm{P}(50 \mathrm{~kg} / \mathrm{ha})$ and $\mathrm{K}(25$ $\mathrm{kg} / \mathrm{ha}$ ) applied to wheat and $\mathrm{N}(30 \mathrm{~kg} / \mathrm{ha}), \mathrm{P}$
(20 kg/ha) and $\mathrm{K}(10 \mathrm{~kg} / \mathrm{ha})$ was applied to direct seeded basmati rice through inorganic sources of nutrients viz., Urea, DAP and MOP in all the experimental plots along with other cultivation practices as per the respective recommended packages.

Out of the recommended doses $50 \%$ of nitrogen along with full doses of phosphorus and potassium were applied at the time of sowing as basal dose to both the crops. The remaining $50 \%$ nitrogen in wheat and direct seeded basmati rice was applied in two equal splits i.e. at crown initiation stage and other just before boot stage in wheat where as in direct seeded basmati rice remaining dose of nitrogen was given at tillering and panicle initiation stage. Herbicides were applied with the help of Knapsac sprayer fitted with flat fan T-jet nozzle using spray volume of 500 litres/hectare. All the weed management treatments were applied as post-emergence in wheat while in rice Pendimethalin @ 1.0 $\mathrm{kg} / \mathrm{ha}$ was applied as pre-emergence with in 24 hours of sowing where as in other treatment Pendimethalin @ $1.0 \mathrm{~kg} / \mathrm{ha}$ (Preemergence) was followed by Bispyribac @ $0.030 \mathrm{~kg} / \mathrm{ha}$ as post-emergence at 30 DAS. Mechanical weeding was done twice at 30 DAS and 60 DAS in both the crops between the crop rows with the help of hand operated wheel hoe. Irrigations were given as per requirement. In paddy crop, the irrigations were given as and when hair line cracks were observed on the field to maintain proper moist conditions during active tillering, vegetative and reproductive phases. Plant protection measures were adopted to maintain proper growth and development of the crop. The microbial studies were conducted by serial dilution-agar-plante method (Agarwal and Hasija, 1986) before the start of the experiment in each crop field and 15 and 30 days after imposition of weed management treatment. 


\section{Statistical Analysis}

The data recorded for various characteristics were subjected to statistical analysis according to procedure outlined by Cochran and Cox (1963). Means values of different components obtained in the experimentation during rabi when wheat was sown were compared using Duncan Multiple Range Test (DMRT) given by Kramer (1957) while Split plot analysis was applied for mean comparisons in rice crop. All comparisons were evaluated at $5 \%$ level of significance.

\section{Results and Discussion}

\section{Effect on weed management on weeds and crops in wheat and DS basmati rice sequence}

It is apparent from the data depicted in Table 1 and 2 that significantly highest control of weeds in wheat was recorded with the tank mix application of $\mathrm{T}_{3}$ (Isoproturon @ 1.0 $\mathrm{kg} / \mathrm{ha}+2,4-\mathrm{D} @ 0.500$ 1/ha) with highest weed control ranging from of $83.2 \%$ compared to the weedy check. Correspondingly, this treatment registered the highest wheat grain and straw yields of 39.25 and $48.58 \mathrm{q} / \mathrm{ha}$, respectively. On the other hand, in direct seeded basmati rice best weed control was achieved with the sequential application of herbicides $\mathrm{W}_{4}$ (Pendimethalin @ $1.0 \mathrm{~kg} / \mathrm{ha}-\mathrm{PE} f b$ Bispyribac @ $0.030 \mathrm{~kg} / \mathrm{ha}$ -PoE) with highest weed control of $85.0 \%$ compared to weedy check. At the same time, this treatment recorded the highest grain and straw yields of 24.39 and $40.17 \mathrm{q} / \mathrm{ha}$, respectively.

The use of herbicides increased crop yields of both wheat and direct seeded basmati rice crops as they provide congenial environment for crop growth and development due to their efficient control of weeds reducing crop-weed competition leading to better expression of yield attributes culminating into higher crop yields.

\section{Effect of weed management practices on soil microbial count in wheat crop field}

Soil microbial studies conducted on the microbial population of bacteria, fungi and actinomycetes in the wheat crop field before the start of the experiment as well as at 15 and 30 days after the imposition of the treatment presented in Table 3, indicates the adverse effect of all the herbicidal applications in causing significant reduction in soil microbial population at 15 and 30 days after treatment imposition compared to weedy check and mechanical weedings at 30 and 60 DAS. All the herbicidal applications resulted in significant reduction in soil microbial numbers but were statistically at par with each other. The treatment $\mathrm{T}_{2}$ (Mechanical weedings at 30 and 60 DAS) recorded non-significant differences in all the three types of soil microbial populations compared to $\mathrm{T}_{1}$ (weedy check), Further, it was observed that after 30 days of the application of herbicides there was marginal improvement in the numbers of bacteria, fungi and actinomycetes under all the treatments.

Significantly lowest microbial counts were recorded 15 days after application of treatment $\mathrm{T}_{3}$ (Isoproturon@1.0 kg/ha +2,4D @ $0.500 \mathrm{l} / \mathrm{ha}$ ) with corresponding values of (Bacteria-18.00 and $18.66 \times 10^{6} \mathrm{cfu}$, Fungi7.43 and $7.14 \times 10^{3} \mathrm{cfu}$, Actinomycetes- 8.63 and $7.62 \times 10^{4} \mathrm{cfu}$ ) compared to $\mathrm{T}_{1}$. Weedy check (Bacteria-24.00 and $25.00 \times 10^{6} \mathrm{cfu}$, Fungi-10.47 and $10.65 \times 10^{3} \mathrm{cfu}$, Actinomycetes- 10.31 and $10.50 \times 10^{4} \mathrm{cfu}$ ) recorded during rabi 2013-14 and 2014-15, respectively. A slight improvement was recorded in microbial population after 30 days of treatment application under the same treatment of $\mathrm{T}_{3}$ (Isoproturon@ $1.0 \mathrm{~kg} / \mathrm{ha}+$ 2,4-D@0.500 1/ha) with analogous values of 
(Bacteria-18.36 and 20.38 X $10^{6} \mathrm{cfu}$, Fungi8.07 and $8.00 \times 10^{3} \mathrm{cfu}$, Actinomycetes- 9.00 and $8.41 \times 10^{4} \mathrm{cfu}$ ) while $\mathrm{T}_{1}$ (weedy check) registered counts of (Bacteria-25.16 and 26.96 X $10^{6} \mathrm{cfu}$, Fungi-11.14 and $11.49 \times 10^{3} \mathrm{cfu}$, Actinomycetes-10.63 and $10.94 \times 10^{4} \mathrm{cfu}$ ) during both rabi 2013-14 and 2014-15, respectively. The reasons ascribed to the initial reduction in soil microbial count is due to the fact that all the chemical herbicidal formulations and their combinations have toxic effect on the soil microorganisms that normally came to notice immediately after these chemicals were applied to the soil while their concentrations were highest in the soil. Later on, microorganisms took part in degradation process and herbicide concentration in soil and their toxic effects decreased resulting in marginal recovery of microbial population after 30 days of treatment application. These findings are in line with those of Balasubramanian and Sankaran (2001); Radivojevic et al., (2004); Gupta et al., (2011); Sharma et al., (2014) and Kumar et al., (2015).

\section{Effect of weed management practices on} soil microbial count in direct seeded basmati rice crop field preceded by wheat

The data presented in the Table 4 reveals that the soil microbial population obtained from the main plots of DS basmati rice field wherein treatments were applied to preceding wheat showed non-significant variations.

All the herbicidal applications in direct seeded (DS) basmati rice under sub plot treatments resulted in significant reduction in soil microbial population both at 15 and 30 days after treatment imposition compared to weedy check. On the other hand, $\mathrm{W}_{2}$ (Mechanical weedings at 30 and 60 DAS) caused non-significant reduction in the microbial population of all three types (Bacteria, Fungi and Actinomycetes) of soil microbes compared to weedy check. Significantly greatest reduction in microbial population was recorded under $\mathrm{W}_{4}$ (Pendimethalin @ $1.0 \quad \mathrm{~kg} / \mathrm{ha} \quad$-PE $f b$ Bispyribac@0.030 kg/ha -PoE) which was, however, statistically at par with the sole application of $\mathrm{W}_{3}$ (Pendimethalin @ $1.0 \mathrm{~kg} / \mathrm{ha}$ -PE). Further, it was observed at 30 days after the imposition of the weed management treatments there was small build up in the soil micro flora under all the treatments.

Soil microbial counts obtained 15 days after imposition of the treatments under $\mathrm{W}_{4}$ (Pendimethalin @ $1.0 \mathrm{~kg} / \mathrm{ha} \quad \mathrm{PE} \quad f b$ Bispyrebac @ $0.030 \mathrm{~kg} / \mathrm{ha}-\mathrm{PoE}$ ) were (Bacteria- 21.49 and $21.87 \times 10^{6} \mathrm{cfu}$, Fungi11.81 and $11.21 \times 10^{3} \mathrm{cfu}$, Actinomycetes8.61 and $9.41 \times 10^{4} \mathrm{cfu}$ ); recorded during both kharif 2014 and 2015, respectively.

The corresponding values of soil microbial population registered at 30 days after the application of weed management treatments under $\mathrm{W}_{4}$ (Pendimethalin@ $1.0 \mathrm{~kg} / \mathrm{ha}$-PE $f b$ Bispyribac @ $0.030 \mathrm{~kg} / \mathrm{ha}-\mathrm{PoE}$ ) were (Bacteria- 22.52 and $22.16 \times 10^{6} \mathrm{cfu}$, Fungi11.78 and $11.65 \times 10^{3} \mathrm{cfu}$, Actinomycetes9.10 and $8.11 \times 10^{4} \mathrm{cfu}$ ) while $\mathrm{W}_{1}$ (Weedy check) registered (Bacteria- 26.83 and 27.74 X $10^{6} \mathrm{cfu}$, Fungi- 12.69 and $13.63 \times 10^{3} \mathrm{cfu}$, Actinomycetes- 12.22 and $11.34 \times 10^{4} \mathrm{cfu}$ ) during both kharif 2014 and 2015, respectively. Interaction effects were found to be non-significant both at 15 and 30 days after the imposition of the treatments.

In both wheat and direct seeded (DS) rice crops Mechanical weedings twice at 30 and 60 DAS has shown minute decline in microbial counts. The possible reason could be that the mechanical weedings disturb upper layer of the soil causing enhanced exposure of the soil microbes to the sunlight which might have resulted in the marginal initial reduction in their population. 
Table.1 Effect of weed management interventions on weeds, grain and straw yield of wheat (Pooled data of two years)

\begin{tabular}{|c|c|c|c|c|}
\hline Treatment & $\begin{array}{c}\text { Weed } \\
\text { count }\left(\mathbf{p e r} \mathbf{~ m}^{\mathbf{2}}\right)\end{array}$ & $\begin{array}{c}\text { Weed } \\
\text { dry weight } \mathbf{( g / \mathbf { m } ^ { 2 } )}\end{array}$ & $\begin{array}{c}\text { Grain yield } \\
(\mathbf{q} / \mathbf{h a})\end{array}$ & $\begin{array}{c}\text { Straw yield } \\
(\mathbf{q} / \mathbf{h a})\end{array}$ \\
\hline $\mathbf{T}_{\mathbf{1}}$ & $\begin{array}{c}13.91 \\
(209.57) \mathrm{a}\end{array}$ & $\begin{array}{c}14.50 \\
(192.56) \mathrm{a}\end{array}$ & $22.35 \mathrm{~d}$ & $29.83 \mathrm{~d}$ \\
\hline $\mathbf{T}_{\mathbf{2}}$ & $\begin{array}{c}5.94 \\
(34.68) \mathrm{d}\end{array}$ & $\begin{array}{c}6.00 \\
(34.33) \mathrm{d}\end{array}$ & $38.60 \mathrm{a}$ & $47.71 \mathrm{a}$ \\
\hline $\mathbf{T}_{\mathbf{3}}$ & $\begin{array}{c}5.78 \\
(33.14) \mathrm{d}\end{array}$ & $\begin{array}{c}5.80 \\
(32.37) \mathrm{d}\end{array}$ & $39.25 \mathrm{a}$ & $48.58 \mathrm{a}$ \\
\hline $\mathbf{T}_{\mathbf{4}}$ & 10.48 & 10.50 & $30.03 \mathrm{c}$ & $40.57 \mathrm{c}$ \\
\hline $\mathbf{T}_{\mathbf{5}}$ & $(98.92) \mathrm{b}$ & $(108.45) \mathrm{b}$ & & \\
\hline
\end{tabular}

Figures in the parenthesis are the original values subjected to $\sqrt{\mathrm{x}}+1$ square root transformations Values within a column followed by a common letter are not significantly different at $5 \%$ level $\mathrm{T}_{1}=$ Weedy Check $; \mathrm{T}_{2}=$ Mechanical Weedings- 2 (30 and $\left.60 \mathrm{DAS}\right) ; \mathrm{T}_{3}=$ Isoproturon @ 1.0 kg/ha + 2,4-D @ 0.500 L/ha (Post-emergence); $\mathrm{T}_{4}=$ Clodinafop @ $0.060 \mathrm{~kg} / \mathrm{ha}$ (Post-emergence); $\mathrm{T}_{5}=$ Triasulfuron @ $0.015 \mathrm{~kg} / \mathrm{ha}$ (Post-emergence)

Table.2 Effect of weed management interventions on weeds, grain and straw yield of DS basmati rice preceded by wheat (Pooled data of two years)

\begin{tabular}{|c|c|c|c|c|}
\hline \multicolumn{5}{|l|}{ Treatment } \\
\hline Weed Management in wheat & Weed count (per $\mathbf{m}^{2}$ ) & $\begin{array}{l}\text { Weed dry } \\
\text { weight }\left(\mathrm{g} / \mathbf{m}^{2}\right)\end{array}$ & $\begin{array}{l}\text { Grain yield } \\
\text { (q/ha) }\end{array}$ & $\begin{array}{l}\text { Straw yield } \\
(\mathrm{q} / \mathrm{ha})\end{array}$ \\
\hline $\mathbf{T}_{1}$ & $11.37(142.98)$ & $9.63(107.28)$ & 16.87 & 27.32 \\
\hline $\mathbf{T}_{2}$ & $10.24(118.29)$ & $8.86(89.60)$ & 17.44 & 30.12 \\
\hline $\mathbf{T}_{3}$ & $10.14(113.56)$ & $8.65(85.61)$ & 17.59 & 30.80 \\
\hline $\mathbf{T}_{4}$ & $10.86(131.45)$ & $9.25(99.42)$ & 17.30 & 29.10 \\
\hline $\mathbf{T}_{5}$ & $10.72(125.14)$ & $8.94(92.54)$ & 17.40 & 29.41 \\
\hline SE m(土) & 0.30 & 0.29 & 0.78 & 1.16 \\
\hline $\operatorname{LSD}(p=0.05)$ & NS & NS & NS & NS \\
\hline \multicolumn{5}{|l|}{ Weed management in rice } \\
\hline $\mathrm{W}_{1}$ & $16.07(259.29)$ & $14.69(216.98)$ & 9.54 & 17.44 \\
\hline $\mathbf{W}_{2}$ & $11.51(131.98)$ & $9.47(89.13)$ & 12.79 & 21.53 \\
\hline $\mathbf{W}_{3}$ & $7.83(61.24)$ & $6.43(40.99)$ & 22.55 & 38.27 \\
\hline $\mathbf{W}_{4}$ & $7.25(52.64)$ & $5.69(32.45)$ & 24.39 & 40.17 \\
\hline SE m( $( \pm)$ & 0.29 & 0.29 & 0.55 & 0.71 \\
\hline $\operatorname{LSD}(p=0.05)$ & 0.83 & 0.84 & 1.87 & 2.05 \\
\hline Interaction Factor B at same level of A & NS & & & \\
\hline Factor $A$ at same level of $B$ & NS & & & \\
\hline
\end{tabular}

$\mathrm{KY}_{1}=$ Kharif $2014 \mathrm{KY}_{2}=$ Kharif 2015

$\mathrm{T}_{1}=$ Weedy Check

$\begin{array}{ll}\mathrm{T}_{2}=\text { Mechanical Weedings-2 }(30 \text { and } 60 \mathrm{DAS}) & \mathrm{W}_{2}=\text { Mechanical Weedings-2 }(30 \text { and } \\ \mathrm{T}_{3}=\text { Isoproturon @ } 1.0 \mathrm{~kg} / \mathrm{ha}+2,4-\mathrm{D} @ 0.500 \mathrm{1} / \mathrm{ha}(\mathrm{Po} \mathrm{E}) \quad \mathrm{W}_{3}=\text { Pendimethaln @ 1.0 kg/ha (PE) }\end{array}$

$\mathrm{W}_{1}=$ Weedy Check

$\mathrm{T}_{4}=$ Clodinafop @ $0.060 \mathrm{~kg} / \mathrm{ha}(\mathrm{Po} \mathrm{E}) \quad \mathrm{W}_{4}=$ Pendimethalin @ $1.0 \mathrm{~kg} / \mathrm{ha}(\mathrm{PE}) f b$ Bispyribac $@ 0.030 \mathrm{~kg} / \mathrm{ha}((\mathrm{PoE}))$

$\mathrm{T}_{5}=$ Triasulfuron @ $0.015 \mathrm{~kg} / \mathrm{ha}(\mathrm{Po} \mathrm{E})$ 
Table.3 Effect of weed management practices on soil microbial count in wheat crop

\begin{tabular}{|c|c|c|c|c|c|c|c|c|c|c|c|c|}
\hline \multirow[b]{3}{*}{ Treatment } & \multicolumn{4}{|c|}{ Bacteria $\left(\times 10^{6} \mathrm{cfu} * *\right)$} & \multicolumn{4}{|c|}{ Fungi $\left(\times 10^{3} \mathrm{cfu}\right)$} & \multicolumn{4}{|c|}{ Actinomycetes $\left(\times 10^{4} \mathrm{cfu}\right)$} \\
\hline & \multicolumn{2}{|c|}{15 DAT* } & \multicolumn{2}{|c|}{30 DAT } & \multicolumn{2}{|c|}{15 DAT } & \multicolumn{2}{|c|}{30 DAT } & \multicolumn{2}{|c|}{15 DAT } & \multicolumn{2}{|c|}{30 DAT } \\
\hline & $\mathbf{R Y} \mathbf{Y}_{1}$ & $\mathbf{R Y}_{2}$ & $\mathbf{R Y}_{1}$ & $\mathbf{R Y}_{2}$ & $\mathbf{R Y}_{1}$ & $\mathbf{R} \mathbf{Y}_{2}$ & $\mathbf{R Y} \mathbf{Y}_{1}$ & $\mathbf{R Y}_{2}$ & $\mathbf{R Y} \mathbf{Y}_{1}$ & $\mathbf{R Y}_{2}$ & $\mathbf{R Y} \mathbf{Y}_{1}$ & $\mathbf{R} \mathbf{Y}_{2}$ \\
\hline $\mathbf{T}_{1}$ & $24.00 \mathrm{a}$ & $25.00 \mathrm{a}$ & $25.16 \mathrm{a}$ & $26.96 \mathrm{a}$ & $10.47 \mathrm{a}$ & $10.65 \mathrm{a}$ & $11.14 \mathrm{a}$ & $11.49 \mathrm{a}$ & $10.31 \mathrm{a}$ & $10.50 \mathrm{a}$ & $10.63 \mathrm{a}$ & $10.94 \mathrm{a}$ \\
\hline $\mathbf{T}_{2}$ & $22.67 \mathrm{a}$ & $24.00 \mathrm{a}$ & $23.07 \mathrm{a}$ & $25.84 \mathrm{a}$ & $10.31 \mathrm{a}$ & $10.38 \mathrm{a}$ & $10.81 \mathrm{a}$ & $10.90 \mathrm{a}$ & $10.14 \mathrm{a}$ & $10.17 \mathrm{a}$ & $10.45 \mathrm{a}$ & $10.77 \mathrm{a}$ \\
\hline $\mathbf{T}_{\mathbf{3}}$ & $18.00 \mathrm{~b}$ & $18.66 \mathrm{~b}$ & $18.36 \mathrm{~b}$ & $20.38 \mathrm{~b}$ & $7.43 \mathrm{~b}$ & $7.14 \mathrm{~b}$ & $8.07 \mathrm{~b}$ & $8.00 \mathrm{~b}$ & $8.63 b$ & $7.62 b$ & $9.00 \mathrm{~b}$ & $8.41 \mathrm{~b}$ \\
\hline $\mathbf{T}_{4}$ & $19.33 \mathrm{~b}$ & $19.00 \mathrm{~b}$ & $20.05 \mathrm{~b}$ & $20.35 b$ & $7.73 \mathrm{~b}$ & $7.44 \mathrm{~b}$ & $8.15 \mathrm{~b}$ & $7.76 \mathrm{~b}$ & $8.98 b$ & $7.71 b$ & $9.11 \mathrm{~b}$ & 8.49 \\
\hline $\mathbf{T}_{5}$ & $19.67 \mathrm{~b}$ & $18.00 \mathrm{~b}$ & $20.32 \mathrm{~b}$ & $19.79 b$ & $7.78 \mathrm{~b}$ & $7.47 \mathrm{~b}$ & $8.15 \mathrm{~b}$ & $7.90 \mathrm{~b}$ & $9.09 \mathrm{~b}$ & $8.30 \mathrm{~b}$ & $9.41 \mathrm{~b}$ & 8.61 \\
\hline Initial status & \multicolumn{2}{|c|}{ Bacteria - 26.89} & \multicolumn{2}{|l|}{25.97} & \multicolumn{2}{|c|}{ Fungi - 10.22 } & \multicolumn{2}{|l|}{11.82} & \multicolumn{2}{|c|}{ Actenomycetes - } & \multicolumn{2}{|c|}{10.9310 .22} \\
\hline
\end{tabular}

*DAT $=$ Days after treatment $\mathrm{cfu} * *=$ Colony forming units

Values within a column followed by a common letter are not significantly different at $5 \%$ level

$\mathrm{RY}_{1}=$ Rabi 2013-14 RY 2 = Rabi 2014-15

DAS $=$ Days after sowing

$\mathrm{T}_{1}=$ Weedy Check; $\mathrm{T}_{2}=$ Mechanical Weedings- 2 (30 and $\left.60 \mathrm{DAS}\right) ; \mathrm{T}_{3}=$ Isoproturon @ $1.0 \mathrm{~kg} / \mathrm{ha}+2$,4-D @ 0.500 L/ha (Post-emergence); $\mathrm{T}_{4}=$ Clodinafop @ 0.060

$\mathrm{kg} / \mathrm{ha}$ (Post-emergence); $\mathrm{T}_{5}=$ Triasulfuron @ $0.015 \mathrm{~kg} / \mathrm{ha}$ (Post-emergence) 
Table.4 Effect of weed management practices on soil microbial count in direct seeded basmati rice

\begin{tabular}{|c|c|c|c|c|c|c|c|c|c|c|c|c|}
\hline \multirow[t]{2}{*}{ Treatment } & \multicolumn{2}{|c|}{15 DAT* } & \multicolumn{2}{|c|}{30 DAT } & \multicolumn{2}{|c|}{15 DAT } & \multicolumn{2}{|c|}{30 DAT } & \multicolumn{2}{|c|}{15 DAT } & \multicolumn{2}{|c|}{30 DAT } \\
\hline & $\mathrm{KY}_{1}$ & $\mathrm{KY}_{2}$ & $\mathrm{KY}_{1}$ & $\mathbf{K Y}_{2}$ & $\mathbf{K Y}_{2}$ & $\mathrm{KY}_{1}$ & $\mathbf{K Y}_{2}$ & $\mathrm{KY}_{1}$ & $\mathrm{KY}_{2}$ & $\mathrm{KY}_{1}$ & $\mathrm{KY}_{2}$ & \\
\hline \multicolumn{13}{|l|}{ Weed management in wheat } \\
\hline $\mathrm{T}_{1}$ & 23.83 & 24.90 & 25.35 & 25.42 & 12.24 & 12.46 & 12.65 & 13.53 & 10.59 & 11.70 & 10.97 & 10.07 \\
\hline $\mathbf{T}_{2}$ & 23.33 & 22.41 & 24.84 & 24.91 & 12.19 & 11.95 & 12.56 & 13.12 & 10.34 & 11.49 & 10.88 & 10.00 \\
\hline $\mathbf{T}_{\mathbf{3}}$ & 23.00 & 23.07 & 24.47 & 24.54 & 12.13 & 11.60 & 12.02 & 12.25 & 10.00 & 11.00 & 10.34 & 9.31 \\
\hline $\mathbf{T}_{4}$ & 23.33 & 23.40 & 24.55 & 24.64 & 12.13 & 11.70 & 12.03 & 12.34 & 10.05 & 11.10 & 10.45 & 9.43 \\
\hline $\mathbf{T}_{5}$ & 23.08 & 23.17 & 24.83 & 24.90 & 12.17 & 11.86 & 12.16 & 12.30 & 10.18 & 11.21 & 10.49 & 9.44 \\
\hline $\operatorname{SEm}( \pm)$ & 0.53 & 0.53 & 0.57 & 0.55 & 0.21 & 0.24 & 0.48 & 0.60 & 0.17 & 0.23 & 0.34 & 0.23 \\
\hline$L S D(p=0.05)$ & NS & NS & NS & NS & NS & NS & NS & NS & NS & NS & NS & NS \\
\hline \multicolumn{13}{|l|}{ Weed management in rice } \\
\hline $\mathbf{W}_{1}$ & 24.93 & 25.54 & 26.83 & 27.74 & 12.54 & 12.62 & 12.69 & 13.63 & 12.03 & 13.05 & 12.22 & 11.34 \\
\hline $\mathbf{W}_{2}$ & 24.60 & 25.12 & 26.19 & 26.40 & 12.35 & 12.30 & 12.59 & 13.55 & 11.28 & 12.80 & 11.95 & 11.00 \\
\hline $\mathbf{W}_{\mathbf{3}}$ & 22.30 & 21.87 & 23.69 & 23.23 & 11.98 & 11.46 & 12.07 & 12.00 & 9.00 & 9.96 & 9.26 & 8.13 \\
\hline $\mathbf{W}_{4}$ & 21.49 & 21.02 & 22.52 & 22.16 & 11.81 & 11.21 & 11.78 & 11.65 & 8.61 & 9.41 & 9.10 & 8.11 \\
\hline $\operatorname{SEm}( \pm)$ & 0.47 & 0.50 & 0.52 & 0.55 & 0.08 & 0.09 & 0.08 & 0.10 & 0.13 & 0.16 & 0.09 & 0.12 \\
\hline$L S D(p=0.05)$ & 1.43 & 1.75 & 1.61 & 2.03 & 0.24 & 0.35 & 0.31 & 0.35 & 0.44 & 0.56 & 0.27 & 0.39 \\
\hline $\begin{array}{c}\text { Interaction Factor B at same level of A } \\
\text { Factor A at same level of B }\end{array}$ & & $\begin{array}{l}\text { NS } \\
\text { NS }\end{array}$ & & & & & & & & & & \\
\hline Initial status & \multicolumn{2}{|c|}{ Bacteria - 26.34 } & \multicolumn{2}{|c|}{27.22} & \multicolumn{2}{|c|}{ Fungi - 14.39} & \multicolumn{2}{|c|}{13.48} & \multicolumn{2}{|c|}{ Actinomycetes } & \multicolumn{2}{|c|}{13.2712 .31} \\
\hline $\begin{array}{l}\mathrm{KY}_{1}=\text { Kharif } 2014 \quad \mathrm{KY}_{2}=\text { Kharif } 2015 \\
\mathrm{~T}_{1}=\text { Weedy Check } \\
\mathrm{T}_{2}=\text { Mechanical Weedings-2 (30 and 60 DAS) } \\
\mathrm{T}_{3}=\text { Isoproturon @ } 1.0 \mathrm{~kg} / \mathrm{ha}+2,4-\mathrm{D} @ 0.500 \\
\mathrm{~T}_{4}=\text { Clodinafop @ 0.060 kg/ha (Po E) } \\
\mathrm{T}_{5}=\text { Triasulfuron @ 0.015 kg/ha (Po E) }\end{array}$ & 1/ha (Po F & ${ }_{4}=$ Pendim & $\begin{array}{l}=\text { Mechan } \\
=\text { Pendim } \\
\text { methalin } 9\end{array}$ & $\begin{array}{l}\mathrm{W}_{1}= \\
\text { ical Wee } \\
\text { hethaln @ } \\
1.0 \mathrm{~kg} /\end{array}$ & $\begin{array}{l}\text { Weedy } \\
\text { dings-2 }(3 \\
1.0 \mathrm{~kg} / \mathrm{h} \\
\text { a (PE) } f b\end{array}$ & $\begin{array}{l}\text { heck } \\
\text { and 60I } \\
\text { (PE) } \\
\text { Bispyrib }\end{array}$ & \$) & $\mathrm{g} / \mathrm{ha}$ & & & & \\
\hline
\end{tabular}


In majority of the observations a slight improvement in the proliferation of soil microbes was noticed at 30 days after the imposition of the herbicidal treatments. The initial reduction in the soil microbial population for few days after the application of herbicidal treatments might be due to the fact that all the chemical formulations produced toxic effect on the soil microbes when their concentrations were maximum in the soil. At latter stages, various herbicide decomposition processes like photodecomposition, chemical decomposition, biological/microbial decomposition etc. acts on it, consequently herbicide concentration in soil and their toxic effects decreased which ultimately showed slow build up in the microbial population that tends towards soil microbial equilibrium.

These results are akin to the research findings of Radivojevic et al., (2004); Chen et al., (2009); Arora et al., (2012); Waseem and Sondhia (2014); Kumar et al., (2015). This is also evident from the data of taken after each crop cycle before the start of new trial wherein soil microbial numbers do not registered much variations from their initial status.

It can be concluded that the chemical herbicides no doubt cause the reduction in the microbial count during initial days after their application but latter on various decomposition processes like photodecomposition, chemical decomposition, biological decomposition etc. take place which ultimately cause gradual build up in the soil microbial population. Therefore, it can be recommended that the herbicide can be used safely for management weeds in wheat and direct seeded basmati rice sequence without any detrimental effects on soil biological health and crop yields. Instead, the application of herbicides helps in attaining better crop yields in both the crops as they reduce crop-weed competition due to their efficient control on multiple weed flora.

\section{References}

Agarwal, G.P. and Hasija SK. 1986. Microorganism in laboratory.A laboratory guide for Microbiology, Mycology and Plant Pathology. Print House, Lucknow, India: pp 137

Angiras, N.N., Kumar, S., Rana, S.S. and Sharma N. 2008. Standardization of dose and time of application of clodinafop-propargyl to manage weeds in wheat. Himachal Journal of Agricultural Research 34(2): 15-18.

Anonymous. 2016-17a. Digest of Statistics. Directorate of Economics and Statistics. Government of Jammu and Kashmir.

Anonymous. 2017. Agricultural Statistics at a Glance 2017. Ministry of Agriculture \& Farmers Welfare Department of Agriculture, Cooperation \& Farmers Welfare. Directorate of Economics \& Statistics. Government of India. Pp-92 Anonymous. 2018. Basmati acreage and yield estimation in Punjab, Haryana, Delhi, Western Uttar Pradesh, Uttrakhand, Himachal Pradesh and parts of Jammu and Kashmir. REPORT-6, Kharif2018. Basmati Export Foundation, APEDA, New Delhi

Anonymous 2014 Agricultural Statistics at a Glance-2014.Government of India, Ministry of Agriculture and Cooperation, Directorate of Economics and Statistics, Oxford University Press, New Delhi, India pp $1-451$.

Anonymous. 2015. Economic Survey 201415, Directorate of Economics and Statistics, J\&K Government, 1:1-297.

Arora, A., Dubey, S. K. and Rajput, R. L. 2012. Persistence of herbicides applied to soybean and its effect on 
soil microbial population. Biennial Conference of Indian Society of Weed Science on "Weed Threat to Agriculture, Biodiversity and Environment", April, 19-20, 2012, Kerala Agricultural University, Thrissur (Kerala), P 32.

Balasubramanian ,V. and Hill, J.E. 2002. Direct seeding of rice in Asia : emerging isuues and strategic research needs for the $21^{\text {st }}$ century. In : Direct seeding : research strategies and opportunities. Proceedings of the International workshop on Direct Seeding in Asian Rice Systems, 25-28 January 2000, Bankok, Thailand

Balasubramanian K and Sankaran S. 2001. Effect of pendimethalin on soil microorganisms. Indian Agriculturist, 45: 93-98.

Chen, W. C., Yen, J. H., Chang. C., S. and Wang, Y. S. 2009. Effects of herbicide butachlor on soil microorganisms on nitrogen-fixing abilities in paddy soil. Ecotoxicology and Environmental Safety, 72:120-7.

Cocharan, W.G. and Cox, G.M. 1963. Experimental Designs. Asia Publishing House. Bombay. India FAO, 2010. httpp:/www.fao.or

Gupta, A., Aggrawal. A., Rathi, $\mathrm{M}$ and Khusbu. 2011. Effect of herbicide clodinafop on AM fungal biodiversity of wheat crop. The Ecoscan. 1: 195199.

Hussain, S., Ramzan, M., Akhter, M. and Aslam, M. 2008. Weed Management in Direct Seeded Rice. Journal of Animal \& Plant Sciences 18 (2-3): 8688.

Johnson D. E (1996). Weed management in small holder rice production in the tropics. National IPM Network, University of Minnesota, 1-8.

Khaliq, A. Matloob, A., Shafiq, H. M. Ata, Z., Cheema, X. Y. and Wahid, A. 2011.
Evaluating sequential application of pre and post emergence herbicides in dry seeded fine rice. Pakistan Journal of Weed Science Research, 17(2): 111-123.

Khaliq, A., Riaz, Y. M. and Matloob, A. 2011. Bio-economic assessment of chemical and non-chemical weed management in dry seeded fine rice (Oryza sativa L.). Journal of Plant Breeding and Crop Science, 3(12): 302-310

Khan, M.A. 2003. Wheat crop management for yield maximization. Agriculture Department, Lahore. Pub. Wheat Research Institute.

Kramer, C.V. 1957. Extension of multiple range test of group correlated adjusted means. Biometrics 13: 13-18.

Kumar, S., Angiras, N.N. and Rana, S.S. 2011. Bio-efficacy of clodinafop propargyl + metsulfuron-methyl against complex weed flora in wheat. Indian Journal of Weed Science 43 (3\&4): 195-198.

Kumar,S., Angiras, N.N., Rana, S.S. and Sharma,N. 2009. Alternative methods of isoproturon application in wheat. Himachal Journal of Agricultural Research 35(1): 31-33

Kumar, R., Badiyala, D., Sharma, N. and Gautam, S. 2015. Effect of long-term application of herbicides on soil microbial demography in rice-wheat cropping sequence. Indian Journal of Weed Science, 47(1): 71-74.

Radivojevic, L., Santric, L., StankovicKalezic, R. and Janjic, V. 2004. Herbicides and soil microorganisms. Biljni LekarPlant Doctor 32: 475-478.

Ramdas, S., Kumar, K. T. M and Singh, G.P. 2019. Wheat Production in India: Trends and Prospects. Open access peer-reviewed Chapter-Online First. doi: 10.5772/ intechopen.86341

Schuster, E. and D. Schroder. 1990. Side 
effects of sequentially applied pesticides on non- target soil microorganisms : Field experiment. Soil Biol. Biochem. 22 : 367-373.

Sharma, V., Yadav, R. S., Singh, S.P. and Bairwa, R. C. 2014. Effect of metsulfuron methyl on microbial population of wheat rhizosphere. Biennial Conference of Indian Society of Weed Science on "Emerging Challenges in Weed Management" February 15-17, 2014, Directorate of Weed Science Research, Jabalpur, Madhya Pradesh, India, pp 59.
USDA. 2019. World Agricultural Production. Foreign Agricultural Service. Office of Global Analysis. pp. 15-16

Waseem, U. and Sondhia, S. 2014. Study of effect of pyrazosulfuron-ethyl on soil fungi. Biennial Conference of Indian Society of Weed Science on "Emerging Challenges in Weed Management", Februry 15-17, 2014. Directorate of Weed Science Research, Jabalpur, Madhya Pradesh, India, $\mathrm{p} 114$.

\section{How to cite this article:}

Akhil Verma, B. C. Sharma, Brij Nandan, Rakesh Kumar and Monika Banotra. 2020. Effect of Weed Management Interventions on Soil Microbial Count in Wheat and Direct Seeded Basmati Rice in Irrigated plains of Shivalik Foothills of Jammu. Int.J.Curr.Microbiol.App.Sci. 9(08): 821-831. doi: https://doi.org/10.20546/ijcmas.2020.908.088 